Roseline GuSUA CASPA ${ }^{1,3}$ Isaac Roger TCHOUAMO ${ }^{2}$ Jean Pierre Mate MWERU ${ }^{1}$ Joseph MBang Amang ${ }^{3}$ Marley NGANG NGWA ${ }^{2}$

1 University of Kinshasa

Regional Postgraduate School of Integrated Tropical Forest and Landscape Management (ERAIFT) P.O. Box 15373

Kinshasa

Democratic Republic of Congo

2 University of Dschang P.O. BOX 96

Dschang

Cameroon

${ }^{3}$ Institute of Agricultural Research for Development (IRAD)

P.O. Box 2123

Yaounde

Cameroon

\section{The place of Irvingia gabonensis in village communities around the Lobeke National Park in Cameroon}

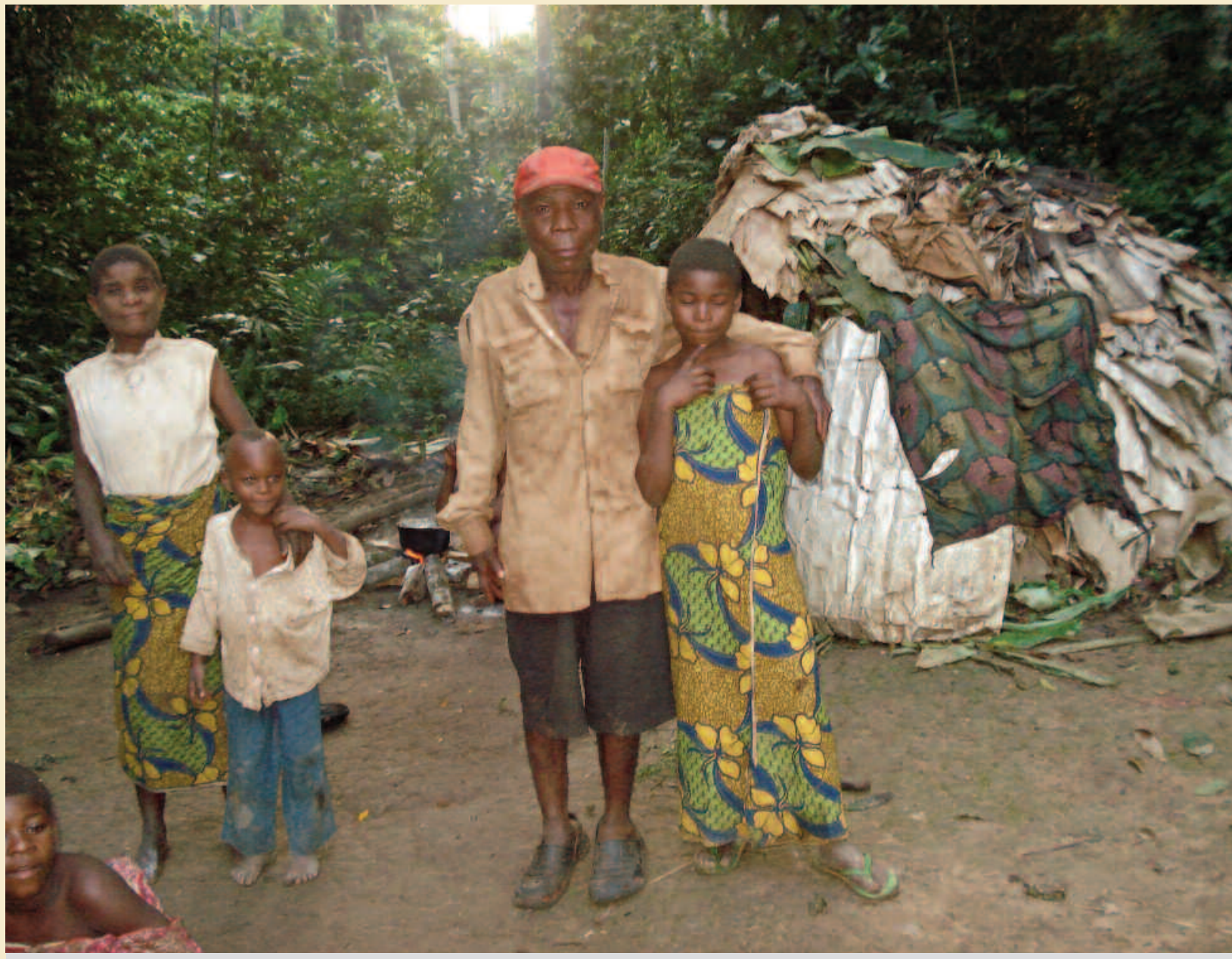

Photo 1.

A Baka family.

Photograph R. G. Caspa, 2013. 
RÉSUMÉ

\section{LA PLACE DE IRVINGIA GABONENSIS DANS LES COMMUNAUTÉS VILLAGEOISES AUTOUR DU PARC NATIONAL DE LOBEKE AU CAMEROUN}

Le manguier sauvage, Irvingia gabonensis, est une des essences les plus exploitées pour des produits forestiers non ligneux aux alentours du Parc national de Lobeke au Cameroun. Une enquête auprès des cueilleurs montre que les fruits sont ramassés en forêt à même le sol, ce qui entraîne des risques élevés d'attaque par des gorilles (100\%) et nécessite de longs séjours en campement ( $87 \%)$. Tous les cueilleurs conservent cette essence, la plupart ( $82 \%)$ en protégeant les semis spontanés, mais ne s'intéressent pas à la plantation. Cependant, près de $68 \%$ des cueilleurs indiquent qu'ils l'envisageraient. L'amande de Irvingia gabonensis est considérée par les cueilleurs comme la deuxième ressource alimentaire (98\%) et la première source de revenus (93\%) parmi les quatre principaux produits forestiers non ligneux de la région. Un inventaire a été réalisé pour évaluer l'abondance de l'essence dans trois systèmes forestiers : la zone protégée, une forêt de production villageoise (forêt naturelle comprise dans le domaine forestier non-permanent et gérée par une communauté villageoise avec l'appui du service forestier) et une zone agroforestière (jachères et associations de cultures/cacao), dans $6 \times 3$ parcelles de 1 ha. La production fruitière a été estimée en comptant les fruits pendant les collectes. La croissance et la survie des plantules n'ont été estimées que dans la zone protégée en raison de la rareté des jeunes plants dans la forêt de production et la zone agroforestière. La densité moyenne des I. gabonensis s'établit à 3,3 arbres/ha, sans écart significatif entre les trois systèmes forestiers. Le diamètre moyen à hauteur de poitrine ne varie pas significativement entre les trois systèmes, ni la production fruitière moyenne. Le taux de survie des semis baisse à $70 \%$ dans la zone protégée au bout de 18 mois. La présence majoritaire d'arbres de diamètre moyen à élevé indique que la ressource se maintiendra pendant quelque temps, mais la quasi absence de jeunes individus permettant de régénérer ces peuplements vieillissants compromet la ressource à plus long terme. L'intensité de la cueillette conduit à recommander l'intégration de cette essence dans les exploitations agricoles villageoises.

Mots-clés : Irvingia gabonensis, ressource vivrière, productivité, Parc national de Lobeke, Cameroun.

\section{ABSTRACT}

\section{THE PLACE OF IRVINGIA GABONENSIS IN VILLAGE COMMUNITIES AROUND THE LOBEKE NATIONAL PARK IN CAMEROON}

The bush mango, Irvingia gabonensis, is one of the most heavily used non-timber tree species around the Lobeke National Park in Cameroon. A survey among fruit gatherers showed that the fruits are collected from the forest floor, which involves very high risks of gorilla attack $(100 \%)$ and long camping periods (87\%). All the gatherers preserve this species, mostly ( $82 \%)$ by protecting wild seedlings, but they are generally reluctant to plant it. However, up to $68 \%$ of gatherers indicated that they would be willing to plant the species. The I. gabonensis kernel was ranked by gatherers (98\%) as the second main source of food and the first main source of income (93\%) among four major Non-Timber Forest Products in the area. An inventory was carried out to determine the abundance of the species in three forest systems: the protected area, a community production forest (a natural forest forming part of the non-permanent forest domain and managed by a village community with the assistance of the forestry administration) and agroforest (fallow land and productive crop/cocoa plantations), in $6 \times 31$-ha plots. Fruit production was assessed by counting fruits during gathering. Seedling growth and survival were assessed only in the protected area because very few seedlings were available in the production forest and agroforest. The overall mean density of $I$. gabonensis was assessed at 3.3 trees per ha, with no significant difference between the three forest systems. The mean diameter at breast height of $I$. gabonensis trees in all three forest systems was not significantly different. Mean fruit production in the three forest systems also showed no significant difference. Seedling survival fell to $70 \%$ in the protected area after 18 months. The presence of mostly medium to large diameter trees is an indication that the resource will continue to be available for some time but the near absence of younger individuals to replace the ageing population is detrimental to resource availability in the long term. Due to the intensity of gathering, it is recommended that the local population should actively incorporate this species into their farms.

Keywords: Irvingia gabonensis, resource base, productivity, Lobeke National Park, Cameroon.
RESUMEN

\section{EL LUGAR DE IRVINGIA GABONENSIS EN COMUNIDADES CAMPESINAS ALREDEDOR DEL PARQUE NACIONAL DE LOBEKE EN CAMERÚN}

El mango africano, Irvingia gabonensis, es una de las especies más explotadas para productos forestales no madereros alrededor del Parque Nacional de Lobeke en Camerún. Una encuesta entre los recolectores muestra que los frutos se recogen en el suelo del bosque, lo que implica un alto riesgo de ataques de gorilas (100\%) y la necesidad de acampar durante períodos prolongados (87\%). Todos los recolectores preservan esta especie, la mayoría (82\%) protegiendo las plántulas silvestres, pero sin pensar en plantarla. Sin embargo, cerca del $68 \%$ de los recolectores dice que estaría dispuesto a hacerlo. La almendra de Irvingia gabonensis es considerada por los recolectores como la segunda fuente de alimento $(98 \%)$ y la primera fuente de ingresos (93\%) entre los cuatro principales productos forestales no madereros de la región. Se efectuó un inventario para evaluar la abundancia de la especie en tres sistemas forestales: el área protegida, un bosque de producción comunitario (bosque natural incluido en el dominio forestal no permanente y manejado por una comunidad campesina con el apoyo del servicio forestal) y una zona agroforestal (barbechos y asociaciones de cultivos con cacao), en $6 \times 3$ parcelas de 1 ha. La producción frutal se estimó contando los frutos durante la recolección. El crecimiento y supervivencia de las plántulas sólo se estimaron en el área protegida debido a la escasez de plantas jóvenes en el bosque de producción y en la zona agroforestal. La densidad promedio de I. gabonensis es de 3.3 árboles/ha, sin variaciones significativas entre los tres sistemas forestales. El diámetro promedio a altura de pecho no varía significativamente entre los tres sistemas forestales, como tampoco lo hace la producción frutal. La tasa de supervivencia de las plántulas desciende al $70 \%$ en el área protegida al cabo de 18 meses. La presencia mayoritaria de árboles de diámetro medio a grande indica que este recurso se mantendrá durante algún tiempo, pero la ausencia casi total de individuos jóvenes que permitan regenerar estos rodales envejecidos hace peligrar este recurso a largo plazo. La intensidad de la recolección lleva a recomendar la integración de esta especie en las explotaciones agrícolas campesinas.

Palabras clave: Irvingia gabonensis, recurso alimenticio, productividad, Parque Nacional de Lobeke, Camerún. 


\section{Introduction}

Irvingia gabonensis (Aubrey-Lecomte ex O. Rorke) Baill. is a large forest tree which grows to a height of $40 \mathrm{~m}$, and is restricted to the forested region from Nigeria to the northern Congo Basin (Sunderland et al., 2002). It is commonly known as bush mango and is economically very important in the regions where it is found. I. gabonensis trees usually reach maturity and begin flowering when they are between 10-15 years old, however, much earlier fruiting has been reported as early as after six years (Ewane et al., 2009). This species features in most lists of priority NonTimber Forest Products (NTFPs) in Cameroon (Ayuk et al., 1999; Clark and Sunderland, 2004; Ingram and Schure, 2010; Egbe et al., 2012). Irvingia gabonensis has been ranked first in terms of its economic and social value in the lowland humid forest zone of Cameroon (Ndoye et al., 1997; Nkwatoh, 1998; Clark and Sunderland, 2004; Tchoundjeu and Atangana, 2012). The species also has enormous potential, both in economic terms and for sustainable production, and could play a significant role in the conservation of the Congo Basin forests (Clark and Sunderland, 2004).

NTFPs are harvested from the wild in natural forests (SCBD, 2001; van Andel, 2006) or from wild stock preserved by local farmers on farms in various traditional agroforestry systems (Tabuna, 2000). Wiersum (1997) identifies three categories of indigenous NTFP management practices including maintenance of the resource stock through (i) controlled utilization and production, (ii) stimulation of the production of required products within existing vegetation, and (iii) stimulating regeneration of valued species. Most farmers maintain mature I. gabonensis trees that are already growing on their land and also transplant wildlings onto their farms or grow new seedlings (Ayuk et al., 1999). According to Tchoundjeu et al. (1999) farmers select seeds from trees that produce high yields of good fruit and may also buy seeds from the market, but the most common source of new stock for cultivation is the forest. Asare (2005) identified I. gabonensis among trees preferred in cocoa agroforests whereas Leakey (1998) proposed it as appropriate for inclusion into multi strata agroforests and for domestication. I. gabonensis trees are one of the most widely used and economically most important among the multipurpose tree species in West and Central Africa (Leakey et al., 2005). Agbor (1994) indicated that the production of bush mango in natural areas was decreasing due to over exploitation and seedling mortality, which points to the urgent need for protection of natural stands because of the rapid increase in demand. According to Marshall et al. (2006), the initial response to increased demand for a NTFP is more intensive harvesting leading to over-exploitation of the species; while in open access conditions, increased value leads to uncontrolled competition for resources and inefficient and damaging harvesting (Belcher and Schreckenberg, 2007). In the same line, the increasing market demand for I. gabonensis almonds causes overexploitation of trees in natural habitats which results in poor regeneration in their postulated genetic diversity centres in Nigeria, Cameroon and Gabon (Ude et al., 2006). The customary rules of access are also changing as the perception of improved marketing opportunities has led to restrictions on access to I. gabonensis (Brown and Lassoie, 2010).
The almond of $I$. gabonensis is also considered a special forestry product by the Ministry of forestry and wildlife in Cameroon which uses the quota system to grant exploitation permits for the resource (Ingram and Schure, 2010). However, the actual quota allocated is usually far below the annual market turnover. For example, in 2009 only one quota was allocated for 100 tons of bush mango almonds from the centre province of Cameroon, whereas studies indicated that in 2007 over 533 tons was produced from just five districts in the Centre, South and Littoral regions (Awono and Manirakiza, 2008) and some 2.8 tons collected annually from the $676 \mathrm{~km}^{2}$ of the Takamanda landscape in the South West region of Cameroon (Tajoacha, 2008).

Lack of knowledge on the availability of NTFP species in their biotope prevents effective planning for their sustainable management which contributes to poverty alleviation (Jiofack et al., 2012). Information on the status of the resource base and the possible impact of harvesting I. gabonensis in the study area is scanty. The lack of yield data is a limitation to the sustainable exploitation of fruits from this indigenous tree species. Irvingia gabonensis was identified among priority species by local communities in the study area because it is a very important source of food and income. In this study, local management consists of practices carried out by local communities to ensure continuous availability of forest products and services. Irvingia gabonensis almonds have become a major object of trade in the study area and this possibly leads to more intense exploitation of the product.

The aim of this study was to assess the abundance and fruit production of $I$. gabonensis in three forest systems including the protected area, production (community) forest and agroforest; and to detail its management and use by the local community.

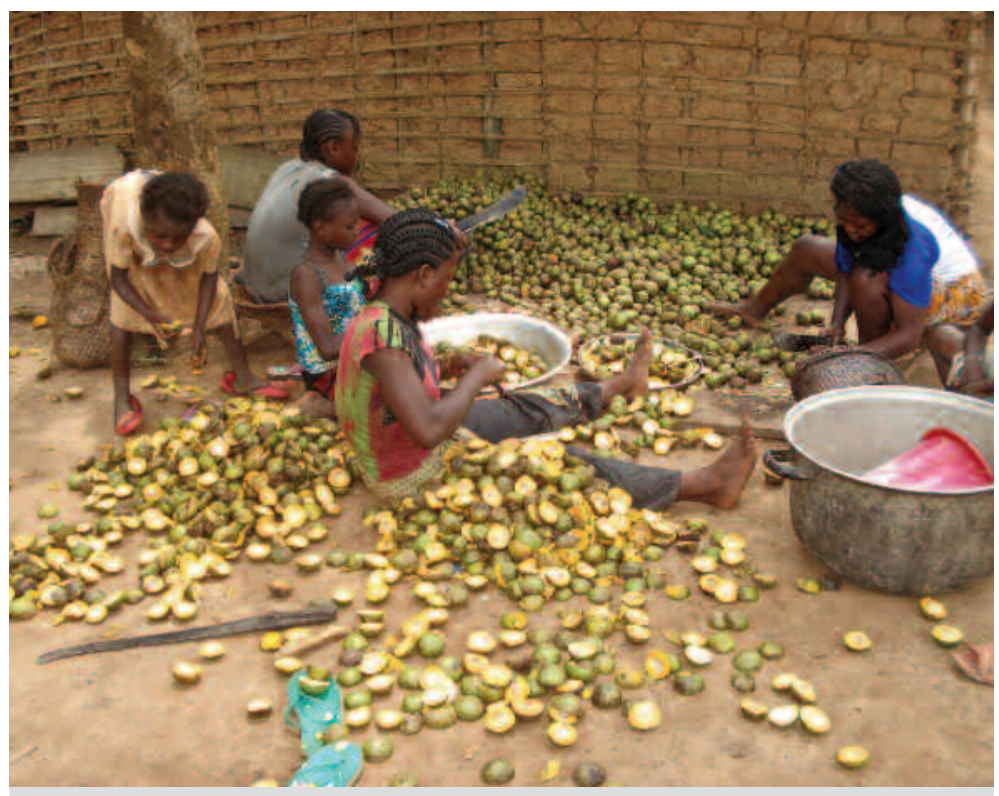

Photo 2.

A Bangando family breaking Irvingia gabonensis fruits. Photograph R. G. Caspa, 2013. 


\section{Materials and Methods}

\section{Study plant}

Irvingia gabonensis is a highly valuable, much-used tropical African tree (Clark and Sunderland, 2004). It grows to a height of $15-40 \mathrm{~m}$, with a slightly buttressed bole and has a dense, compact evergreen crown. It also has yellowish to greenish-white flowers and broadly ellipsoid fruits of 5$7.5 \mathrm{~cm}$ which are yellowish when ripe (Orwa et al., 2009). Irvingia gabonensis occurs naturally in lowland forests with 2-3 trees occurring together. It is a species of dense moist forest and occurs at an altitude of 200-500 m, with a mean annual temperature of $25-32^{\circ} \mathrm{C}$ and mean annual rainfall of 1,500-3,000 mm. According to FAO (1982), it does not have any particular soil preference, except that it avoids swampy or marshy places. The species grow well in well drained acidic soils and is native to Angola, Cameroon, Central African Republic, Congo, Cote d'Ivoire, Democratic Republic of Congo, Equatorial Guinea, Gabon, Ghana, Guinea-Bissau, Liberia, Nigeria, Senegal, Sierra Leone, Sudan and Uganda (Orwa et al., 2009). The species is currently listed in the category of the IUCN red-list (IUCN, 2013).The almonds are used as condiment and soup thickener. The fruit is of secondary importance and used for juice, jelly, jams and wine (Ewane et al., 2009) and sometimes also fed to pigs (Ayuk et al., 1999). Irvingia gabonensis bark is also administered for stomach pain and dysentery (Okolo et al., 1995) as well as for hernias and yellow fever, and as an antidote to some poisons (Ayuk et al., 1999).

\section{Study site}

This study was carried out at the Lobeke National Park in Cameroon. It is situated between latitudes $2^{\circ} 05^{\prime}$ to $2^{\circ} 30^{\prime}$ North and longitudes $15^{\circ} 33^{\prime}$ to $16^{\circ} 11^{\prime}$ East (figure 1). The Lobeke National Park (LNP) has a surface area of about 217,854 hectares and is found in the Moloundou Sub Division of the Boumba and Ngoko Division of the East Region of Cameroon. It forms part of a trans-boundary protected area (the Sangha Tri-National Landscape) with the Dzanga-Sangha National Park in the Central African Republic and the Nouabalé-Ndoki National Park in the Republic of Congo (Gwet, 2004). It is also a UNESCO World heritage site. The climate of the area is typically equatorial with four seasons - two rainy and two dry seasons. The long rainy season extends from September to November with its peak in October while the short rainy season extends from late March to June with its peak in April. The long dry season extends from December to February while the short dry season is between July and August (Ekobo, 1995). The annual rainfall averages $1,500 \mathrm{~mm}$. The mean monthly temperature varies between 23 and $25^{\circ} \mathrm{C}$ with a mean annual temperature of $24^{\circ} \mathrm{C}$. The relative air humidity also varies from 60 to $90 \%$ (WWF, 2006). This area was chosen for the study because of the increasing importance of NTFPs to the local population in the Lobeke landscape.

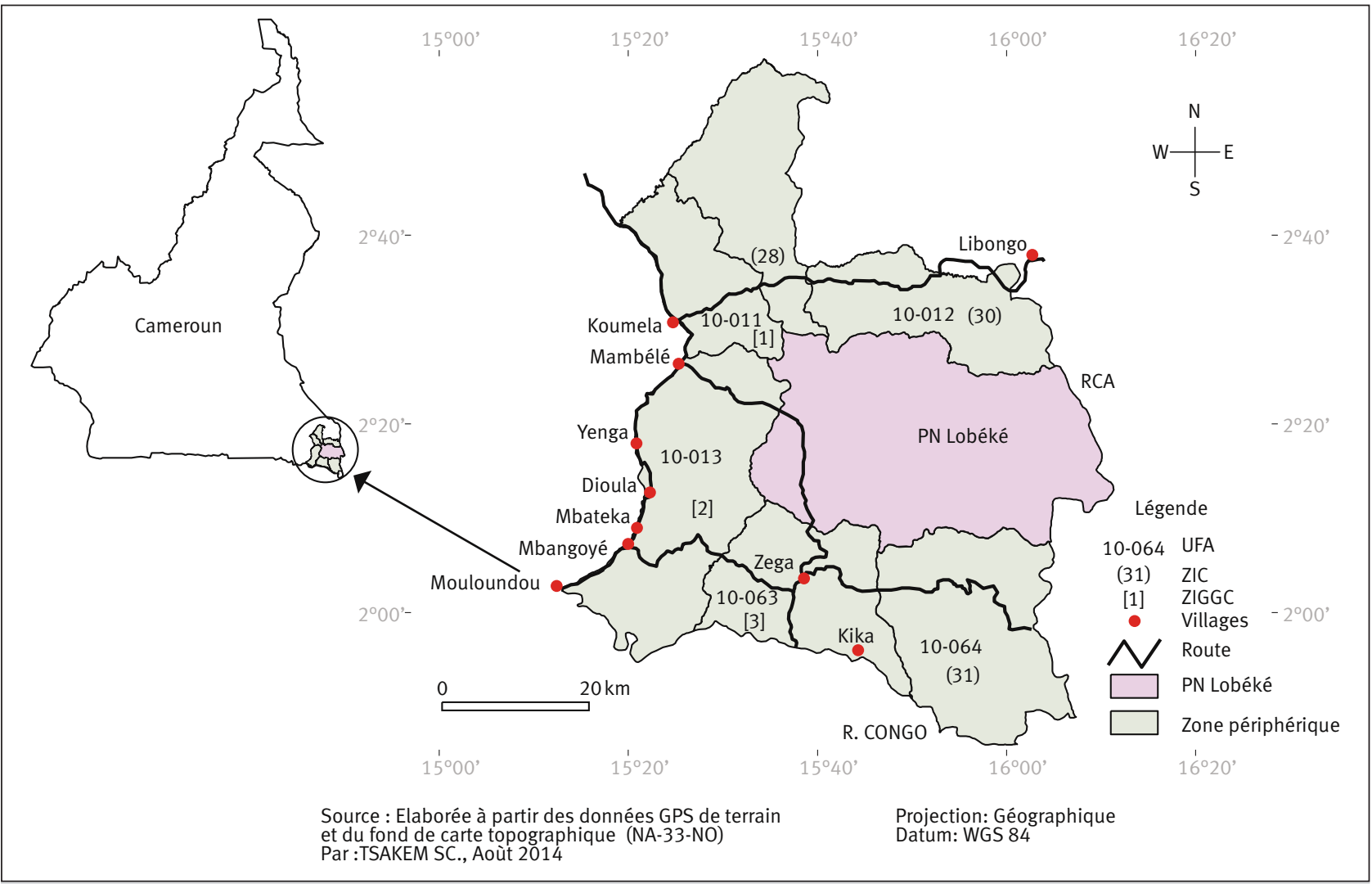

Figure 1.

Location map of the Lobeke National Park. Adapted from Tsakem et al. (2014). 


\section{Survey}

A survey was conducted in nine villages (Koumela, Mambele, Yenga, Dioula, Mbateka, Mbangoye 2, Zega, Kika and Libongo) within the Lobeke landscape. These villages were chosen based on their close proximity to the park. Semi structured questionnaires were administered to collectors who have been involved in the exploitation of I. gabonensis for at least five years, with the objective of getting the perceptions and attitudes of inhabitants towards the management and use of the resource.

\section{Ecological Assessment}

\section{Site description}

Three sites were used for this assessment including protected area, production forest and agroforest. The creation and management of protected areas and the zoning plan carried out between 1999 and 2001 by the Cameroon government with the support of World Wide Fund for Nature (WWF) and German Technical Cooperation (GTZ) came with many restrictions on resource and land use (Njounan Tegomo et al., 2012). The protected area is the core area of the park which forms part of the permanent forest domain and experiences very limited and controlled human access. It was considered as having undergone minimal disturbance and having a closed canopy. The production forest plots were established within a community forest in which there is active exploitation of timber and non-timber forest resources. A community forest in Cameroon is a natural forest that forms part of the non-permanent forest estate, which is covered by a management agreement between a village community and the forestry administration. Management of such forest which should not exceed 5,000 ha, is the responsibility of the village community concerned, with the help or technical assistance of the forestry administration. The agroforest plots were set up within the agroforestry zone which is classified as non-permanent forest. This area is characterized by fallows and active agricultural land including cocoa plantations. It is relatively open, with most of the tree cover removed as a result of the practice of slash and burn agriculture which is predominant in the area.

\section{Inventory}

An inventory was carried out to assess the structure, abundance and regeneration of $I$. gabonensis in the study area. Eighteen plots $(6 \times 3)$ of 1 ha separated from each other by a distance of $200 \mathrm{~m}$ were systematically set in each of three systems including protected area, production forest (community forest) and agroforest (fallow land and active agricultural land/cocoa plantation). All individuals of

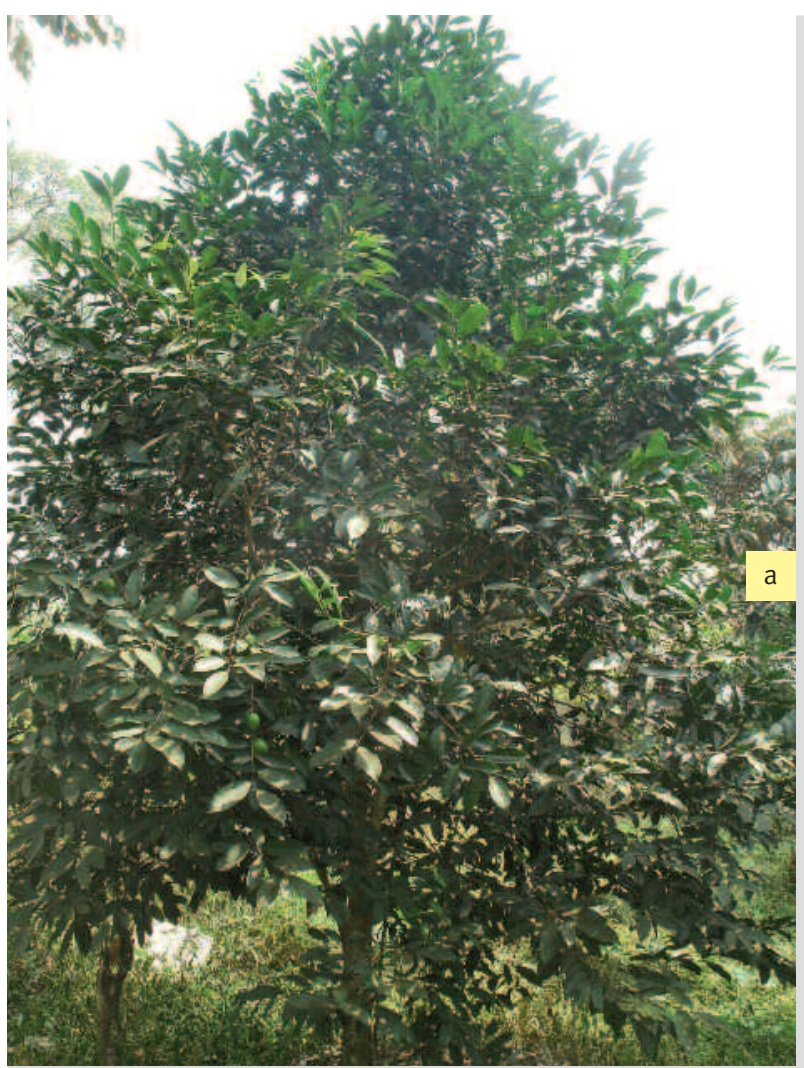

Photos 3.

Irvingia gabonensis planted (a), fruit as food (b), cakes for consumption (c).

Photograph R. G. Caspa, 2013.
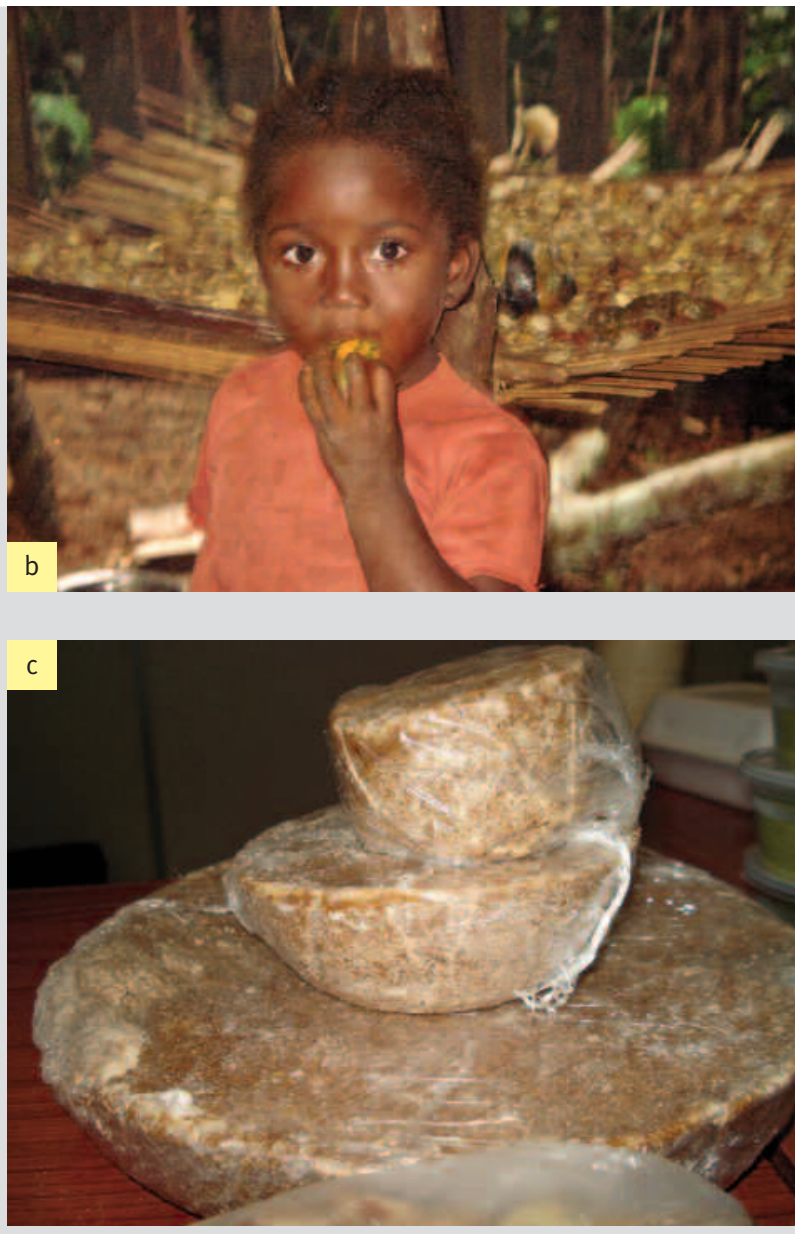


\section{Results}

I. gabonensis with at least $10 \mathrm{~cm}$ diameter at breast height $(\mathrm{DBH})$ were tagged, counted and measured for $\mathrm{DBH}$ in each plot. Each plot was divided into sub plots of $5 \times 100 \mathrm{~m}$. Younger trees of 5-9 cm DBH and saplings (young plants of 1. gabonensis greater than $1 \mathrm{~m}$ height but less than $5 \mathrm{~cm} \mathrm{DBH}$ ) were counted and measured in ten alternating sub plots per plot. Regeneration plots of $2 \times 2 \mathrm{~m}$ were set at $50 \mathrm{~m}$ into each sub plot for enumeration and height measurement of seedlings (Wong, 2000). Fifty seedlings were selected and tagged under five widely separated productive trees (within and out of sample plots depending on availability) in the protected area making a total of two hundred and fifty seedlings. Seedling survival and growth were determined by counting number of surviving seedlings, number of leaves per seedling and measuring seedling height and collar diameter every three months for eighteen months. Very few seedlings of $I$. gabonensis were found in the production forest and agroforest probably due to the high level of fruit collection in these areas and so were excluded from this assessment. Fifteen trees (both within and outside of sample plots) were identified and tagged for fruit production estimate in each forest system. Since the fruits of I. gabonensis are highly collected in the area, fruit production was estimated by counting fruits from each tree during fruit fall (between June and August) before they were collected. This is because people were likely to collect the fruits in our absence if the trap and count method was used.

\section{Data Analysis}

Data were analyzed using the SAS statistical package Version 9.0, with the General Linear Model Procedure (GLM) and the Student-Newman-Keuls test used to compare the means at the level of $\alpha=5 \%$.

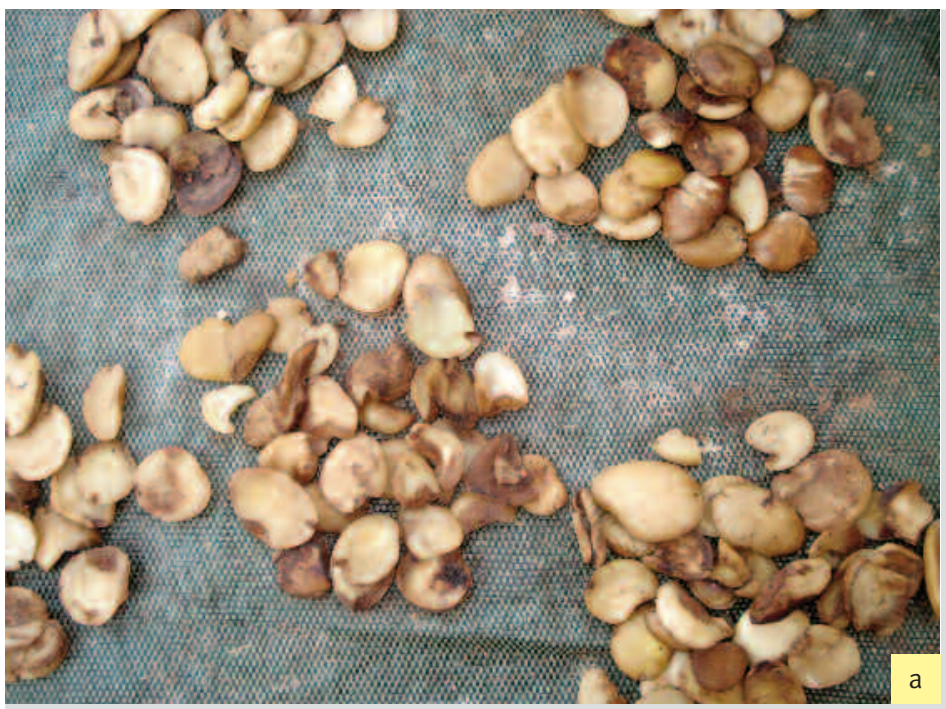

Photos 4.

I. gabonensis almonds for sale in heaps (a), in "kombo" (b), Photograph R. G. Caspa, 2013.

\section{Survey}

The outcome of the survey revealed that respondents (collectors of $I$. gabonensis) had varying ethnic origins. Collectors of $I$. gabonensis came from two major ethnic groups Bangando (53\%) and Baka (29\%). A small proportion of collectors came from six other groups in the East region of Cameroon including Mbimo (8\%), Bapwele (6\%), Baya (1\%), Essel (1\%) Kako (1\%) and Kounabembe (1\%).

\section{Collection of Irvingia gabonensis}

All respondents in this study indicated that they collect 1. gabonensis fruits by picking from the forest floor. This is probably sustainable as no harm is done to the parent plant. Up to $65 \%$ of respondents collect fruits of $I$. gabonensis daily when trees are located in farms or nearby forest patches, but go camping in the forest for periods of two weeks to one month when the resource is far in the forest. This enables them to collect and break large quantities of fruits to extract the almond which is the most desired product. Respondents indicated that the resource is more abundant in the forest than around homesteads or farms. All good fruits are collected.

Some $35 \%$ of respondents indicated that they collect the resource two to five times per week. It was also indicated that people from different households can collect fruits from the same $I$. gabonensis trees at the same time. Although collectors had free access to the product, they highlighted some problems encountered in the collection of fruits of I. gabonensis. All (100\%) respondents indicated that they suffered attack from wild animals (especially

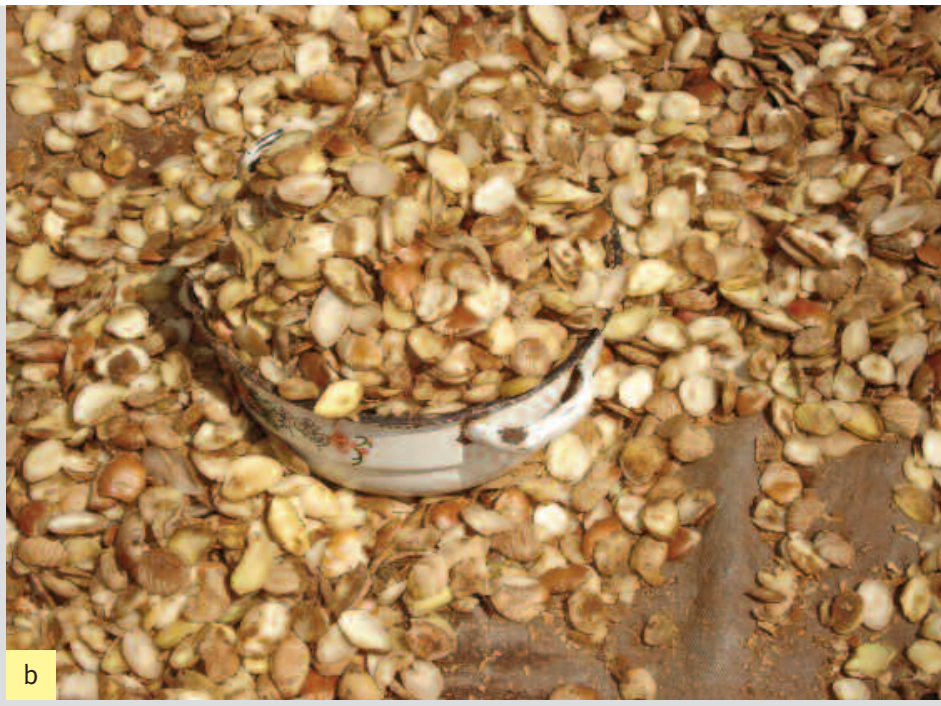




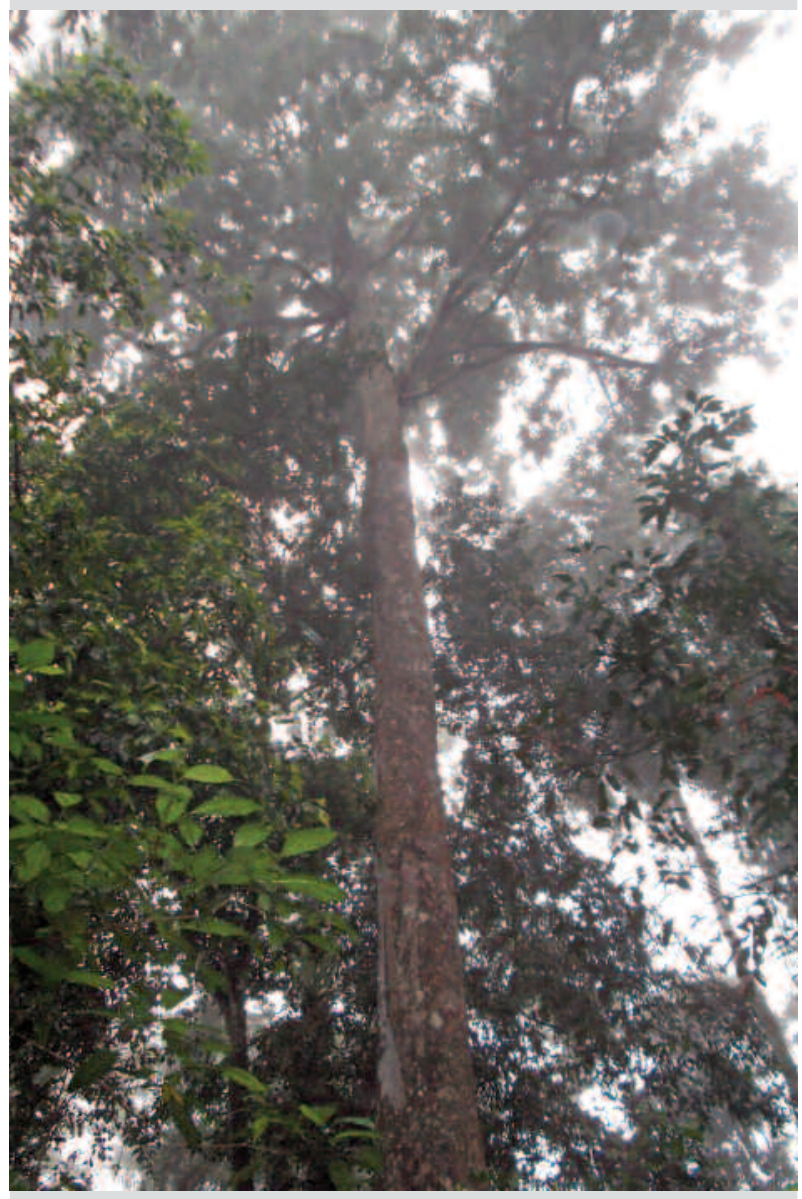

Photo 5.

I. gabonensis tree in secondary forest.

Photograph M. N. Ngwa, 2013.

Gorilla gorilla) which also feeds on the fruits while $87 \%$ observed that they camped for too long in the forest to be able to collect an appreciable quantity of the product. On the other hand, $24 \%$ of collectors indicated that they had to walk long distances to the forest which also made transportation of the produce back home very difficult. Some $15 \%$ of collectors indicated that they ran out of food supply while camping in the forest while $10 \%$ said that there was no fruit production in some years. Some $4 \%$ of respondents indicated that they lacked authorization to collect the resource from the protected area while another $4 \%$ indicated that there was much pressure on the resource as many people collected fruits from the same tree at the time. It should be noted here that responses were not mutually exclusive as most respondents cited more than one problem.

\section{Conservation of Irvingia gabonensis by collectors}

All respondents in this study indicated that they conserve I. gabonensis and a majority ( $82 \%$ ) did so by protecting wildlings. They weeded or cleared around the young plants in their farms or forest and also placed pegs around them to show their presence. A small proportion (6\%) however planted I. gabonensis on their farms. The planting mate- rials were generally seedlings uprooted from the forest. Nevertheless, it was observed that one male respondent owned a nursery with mostly conventional fruit tree seedlings and some indigenous trees seedlings like I. gabonensis produced from seeds or collected from the forest and nurtured in polythene bags. He did not have a market for the seedlings so he planted some on his farm and also offered some as gift. Others (11\%) indicated they protected producing trees by not felling or burning around them when opening up new forest areas during farm creation. Up to $85 \%$ of respondents indicated they had less than 10 trees of $I$. gabonensis in their farms while only $15 \%$ of respondents had between 10 and 20 trees of this species in their farms.

As concerns respondents' attitudes towards planting $/$. gabonensis trees, $68 \%$ indicated that they were willing to plant while $32 \%$ of respondents indicated they were not willing to plant. Of those who were willing to plant, $22 \%$ were to plant for future generations while $19 \%$ of collectors were to plant to facilitate access to the product. Other reasons were to increase production (10.8\%), increase income (7.4\%), ensure ownership (6.5\%) and to improve quality through selection (2.4\%). Of those who were not willing to plant, $18.7 \%$ thought that $I$. gabonensis was abundant in the forest, $7.3 \%$ thought that the tree grows naturally or are planted by God, $4 \%$ indicated that the trees take too long to grow while $2 \%$ indicated that they were ignorant on how to plant.

\section{Uses of Irvingia gabonensis in the Lobeke landscape}

The greater part of collectors (93\%) ranked I. gabonensis almonds as first major source of income among other priority NTFPs in the study area including Gnetum buchholzianum Engl., Gnetum africanum Welw., Ricinodendron heudelotii (Baill.) Heckel and Aframomum pruinosum Gagnep. All respondents indicated that the proceeds from the sale of almonds are used mainly for the education of their children through payment of tuition fees and provision of school needs, for healthcare through payments for medication and for the provision of household needs such as utensils and other food items which they do not produce and basic necessities such as salt and kerosene. Almost all NTFP collectors (98\%) ranked I. gabonensis almonds as the second most important source of food. Less than half of respondents (45\%) indicated they prepared up to $0.5 \mathrm{~kg}$ of $I$. gabonensis almonds in a meal and consume this product almost on a daily basis during production period (June to August), while $55 \%$ prepared about $0.25 \mathrm{~kg}$ per meal for about two to five times per week during production period. The quantity prepared at a time generally depends on desired thickness of soup and family size to a smaller extent. The almonds are usually crushed in a mortar and pressed in a basket to extract edible oil. The resulting cake/lump is put in a bag and stored in a traditional drier over a fire place to avoid spoilage and may last up to a year. Pieces of this cake are chopped off, further crushed and used to prepare soup in periods of scarcity of the product. All respondents also indicated that they preferred I. gabonensis almonds for food to its conventional substitutes (groundnuts, palm nuts, melon seeds, okra pods) because it is collected freely from the 
forest and forms part of their traditional meals. They also revealed that soup prepared with I. gabonensis almonds does not easily get bad.

Bush mango also has cultural and medicinal values in the Lobeke landscape. Few collectors (18\%) indicated that the macerate of bark of this species is used for ceremonial cleansing when a person loses a parent or spouse while $44 \%$ indicated that it had medicinal values. The decoction of its bark was said to be used for treating some ailments notably lower abdominal pain in women.

\section{Inventory}

Figure 2 shows the mean diameter at breast height of $I$. gabonensis in three forest systems around the LNP. According to figure 2, no significant differences were observed in the diameters at breast height of I. gabonensis trees in all forest systems.
The results of I. gabonensis density in the three forest systems (figure 3) show that the protected area had a significantly higher mean density of seedlings (2.6a) than the production forest which also had a significantly higher mean density of seedlings (1.5b) than the agroforest (0.6c) at $P<0.0001$. On the other hand, the agroforest had a significantly higher mean density (0.3a) of trees with DBH of less than $10 \mathrm{~cm}$, than the production forest $(0.1 \mathrm{~b})$ and protected area $(0.1 \mathrm{~b})$ which were not significantly different from each other at $P<0.0001$. The agroforest had a significantly higher mean density (2.1a) of I. gabonensis trees with DBH between 10 and $50 \mathrm{~cm}$ than the production forest which also had a significantly higher mean density (1.6b) of trees of the same size class than the protected area (1.5c) at $\mathrm{P}<0.0001$. For I. gabonensis trees of 51 to $100 \mathrm{~cm} \mathrm{DBH}$, the mean density is significantly higher (1.3a) in the protected area than in the agroforest (1.0b) and production forest (1.0b) between which there was no significant difference at $P<0.0001$. There was equally no significant difference in the mean density of $I$. gabonensis trees of greater than $100 \mathrm{~cm}$ DBH in the agroforest $(0.3 a)$, production forest $(0.3 \mathrm{a})$ and protected area $(0.3 a)$ at $P<0.0001$. The standard error was zero (0) in all cases probably because the values of the data were very close to the mean or because the population mean was close to 0 (McHugh, 2008). The overall mean tree density for all forest systems was 3.3 trees per hectare. The Student-Newman-Keuls test was used at the level of $\alpha=5 \%$.

The results of fruit production from I. gabonensis trees in the three forest systems show that the mean number of fruits in the production forest was 2,523.1 \pm 298.7a,

Mean DBH of Irvingia gabonensis trees in three forest systems around the LNP Means with the same letter are not significantly different.

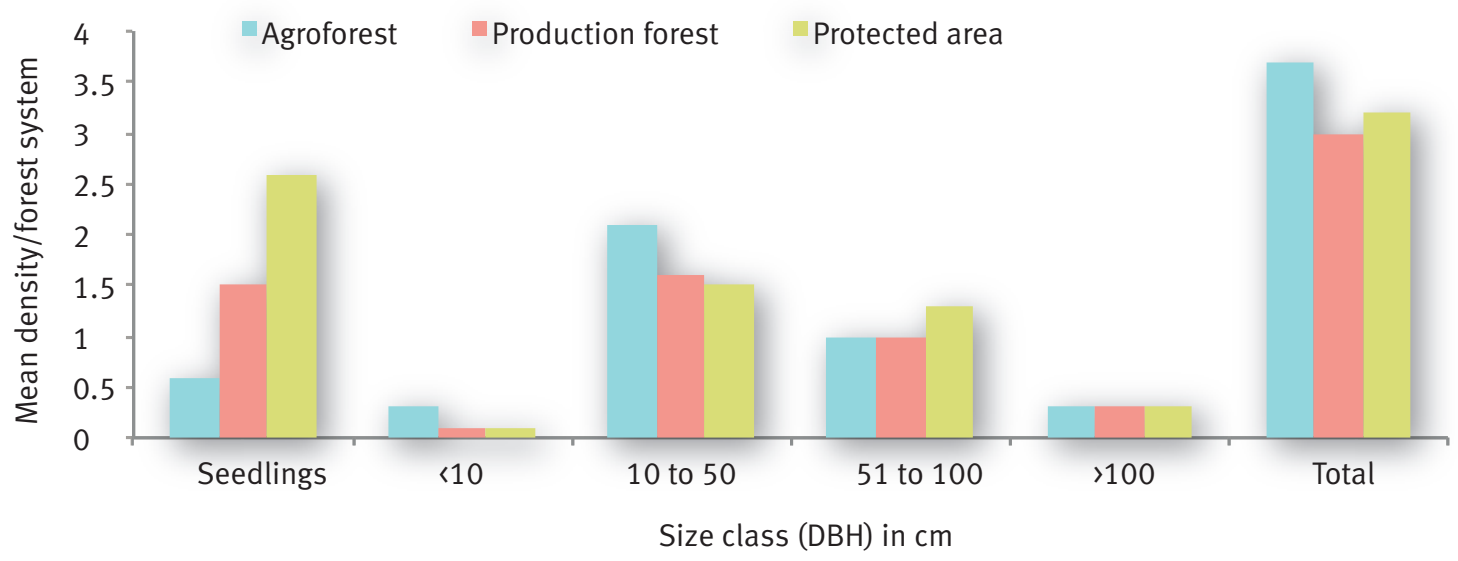

Figure 3.

Mean density of Irvingia gabonensis trees in three forest systems around the LNP.

Means with with the same letter are not significantly different. Size class is expressed in diameter at breath height (DBH). 
$2,566.6 \pm 363.9 a$ for the protected area and $2,892.3 \pm 508.8$ a for the agroforest. With the StudentNewman-Keuls test, there was no significant difference in fruit production in the three forest systems at $\alpha 5=\%(P=0.7774)$.

An assessment of $I$. gabonensis seedling growth parameters in the protected area showed a steady but significant increase in mean seedling height with time $(P<0,001)$ (table I). A progressive and significant increase was also observed in the mean number of leaves and mean seedling collar diameter of I. gabonensis seedlings with time. On the other hand, seedling survival was observed to fall from $100 \%$ to about $70 \%$ after 18 months. It is not certain if these seedlings resulted from germination of seeds of the previous year's fruit fall.

\section{Discussion}

The outcome of the survey reveals the importance of $I$. gabonensis to the communities in the study area. The Bangando and Baka pygmies form a major proportion of collectors because they are the original inhabitants of the area. The fact that other tribal groups are involved indicates that access to the product is still relatively free, unlike in the South West region of Cameroon where only primary inhabitants of a village are allowed to collect the resource freely while settlers/foreigners pay some fee to the village council to be allowed access to the resource (Sunderland et al., 2002; Tajoacha, 2008).The diversity of ethnic groups could constitute a source of difference and disunity concerning the creation of common initiative groups or cooperatives through which NTFPs and agricultural products are better valorized for the benefit of collectors or producers as the case may be.

Since collectors are interested in the almonds contained in fruits, coupled with the fact that most productive trees are tall and large, climbing is precluded as ripe fruits fall from the trees naturally. Collectors'desire to go home with as much fruits/almonds as possible push them to gather all available fruits without any thought of leaving some behind to regenerate the forest. This is detrimental to the sustainability of the species. On the other hand, the few undesirable fruits left under trees may be of poor genetic quality to regenerate the forest. Likewise, Ndoye et al. (1997) observe that the harvesting of I. gabonensis fruits is sustainable and non-destructive, but point out that it may have a long-term effect on the tree and could affect the population structure of the species. Gorillas (Gorilla gorilla) eat the fruits but discard the seeds which also contribute to regenerating the forest. This is a clear indication that most of the fruits are gathered from trees that have not been deliberately planted. Majority of the problems raised by collectors are linked to the fact that most I. gabonensis collection sites are far off from the villages and accessed mostly through foot paths. I. gabonensis fruits make up a large part of the diet of gorillas (Beaume et al, 2012; pers. obs., 2013), hence they are a major source of conflict as concerns the collection of this resource.

The fact that all respondents try to conserve I. gabonensis is an indication of their recognition of its importance in sustaining their livelihoods. Shifting cultivation/slash and burn agriculture is the predominant agricultural practice in the area, so collectors encounter I. gabonensis trees when creating new farms and protect them. The poor attitude of collectors towards planting I. gabonensis can be explained by the fact that collectors have also been used to gathering this product for generations and the small number of trees on their farms may be as a result of very few available wildlings to protect as collection of fruits is very intensive. Baka pygmies who form up to $29 \%$ of collectors are traditional forest migrants moving from place to place (although they are now getting settled in villages) and living solely on gathering of forest products and hunting, with no culture of planting trees or even crops. The small proportion of collectors who indicated that they had more than ten trees on their farms are possibly those who own cocoa plantations with large surface areas and preserve/plant this species not only for its fruits but also for shade provision. Irvingia gabonensis is one of the NTFPs species found in most cocoa agroforests in Cameroon (Mbile et al., 2009).

Table I.

Mean growth parameters and survival of Irvingia gabonensis seedlings in the protected area.

\begin{tabular}{|c|c|c|c|c|c|c|}
\hline \multirow[b]{2}{*}{ Parameter } & \multicolumn{6}{|c|}{ Time } \\
\hline & T1 & T2 & T3 & T4 & T5 & T6 \\
\hline Mean seedling height $(\mathrm{cm})$ & $32( \pm 0.33) a$ & $37( \pm 0.35) b$ & $43( \pm 0.39) c$ & $48( \pm 0.38) d$ & $54( \pm 0.4) \mathrm{e}$ & $60( \pm 0.41) f$ \\
\hline Mean leaf number & $3.6( \pm 0.04) \mathrm{a}$ & $4.5( \pm 0.05) b$ & $5.7( \pm 0.06) c$ & $7.1( \pm 0.07) d$ & $8.3( \pm 0.08) \mathrm{e}$ & $9.6( \pm 0.08) f$ \\
\hline Mean seedling diameter (mm) & $3( \pm 0.01) \mathrm{a}$ & $3.1( \pm 0.02) b$ & $3.9( \pm 0.02) c$ & $4.7( \pm 0.03) d$ & $5.3( \pm 0.02) \mathrm{e}$ & $5.9( \pm 0.09) f$ \\
\hline Seedling Survival (\%) & 100 & 94.4 & 91.6 & 83.2 & 80 & 78 \\
\hline
\end{tabular}


The fact that up to $98 \%$ of respondents ranked $I$. gabonensis as first major source of income among four major NTFPs could be due to the fact that it is one of the available few income sources as there are very few or no formal jobs in the area that can yield a monthly salary. The presence of logging and mining companies in the area also attract settlers who seek jobs in these companies but remain in the zone when these companies close their activities and resort to the collection of NTFPs.In this study, all respondents indicated that the proceeds from the sale of $I$. gabonensis almonds are used to pay for education of children, provide healthcare and household needs. This is in line with the findings of Ingram et al. (2012) and Tieguhong and Ndoye (2006), who found that incomes from forest products play important roles in buying agricultural implements and purchasing basic household needs as well as sending children to school. The fact that all respondents preferred soup prepared with I. gabonensis almonds to other conventional thickeners indicates that there is a strong tie between the local population and forest products which they have been used to consuming. This is supported by (Tieguhong and Zwolinski, 2008) who observed that dependence on forest products is not related to individual household incomes, as wealthier households remain dependent on forest-derived products. This indicates that the traditional link to forests cannot be easily changed through subsidies and compensations.

Inventory showed no significant differencein mean tree DBH for I. gabonensis in all forest systems. This is probably because this tree species is being protected by locals because of its economic benefits such that the level of forest degradation or human interference does not affect its population structure in any of the forest systems. According to van Dijk (1997), I. gabonensis prefers undisturbed lowland tropical forest. There was also no significant difference in the mean density of I. gabonensis with a mean density of 3.3 trees/ha. According to Ghazoul and Sheil (2010), factors that control tree density and diversity in rain forest include natural and anthropogenic disturbances, climate, soil drainage, other soil characteristics, most of which do not differ much between the three forest systems. I. gabonensis has a

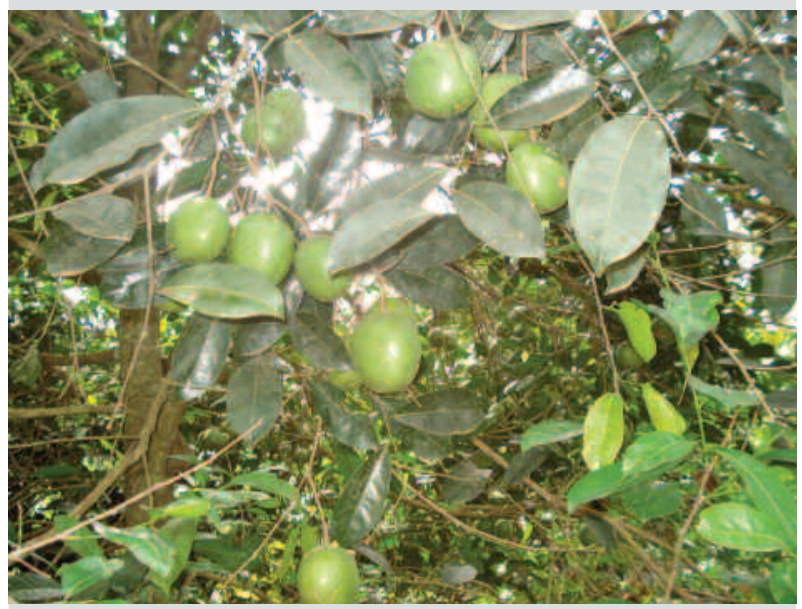

Photo 6.

Fruiting branch of $I$. gabonensis.

Photography R. G. Caspa, 2013.

moderate density in the South of Cameroon, with an average of 2.1 stems/ha, an even distribution and found in every habitat type (van Dijk, 1997). On the other hand, Sunderland et al. (2002) reported that there were relatively few large-diameter individuals ( $>10 \mathrm{~cm} \mathrm{DBH})$ at the Takamanda forest reserve, indicating that there were less productive trees in the area as a result of poor recruitment and probably due to significant over-harvesting of fruit over time. In like manner, Agbor (1994) relates that the density of the species in the tropical moist forest zone of Nigeria is low, as a consequence of high mortality of younger trees, low recruitment rate into the mature age classes and the absence of intensive cultivation of this species and suggesting that this may be the case for most areas in which I. gabonensis grows.

The presence of more seedlings in the protected area could be due to limited access such that people do not gather as much fruits here as in the agroforest and production forest which are freely accessed. This notwithstanding, the total number of seedlings observed was small. This could also be as a result of poor recruitement (Agbor, 1994).
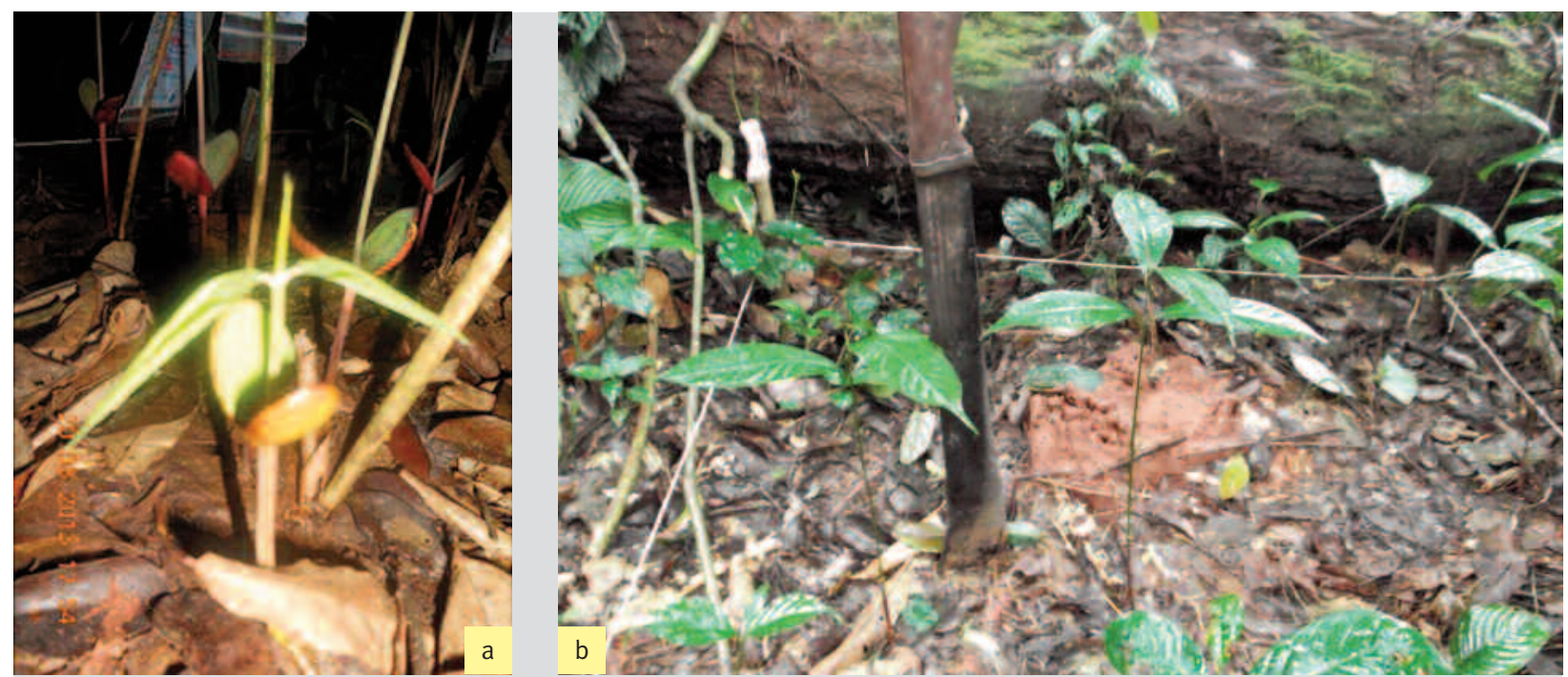

Photos 7.

Young seedling of $I$. gabonensis (a). Seedlings of I. gabonensis (b).

Photograph R. G. Caspa, 2013. 
Mainly productive individuals of this species are found in the forest in the study area. This is possibly due to younger plants being hindered at some point in their growth process by some physical or biological factor from attaining the larger size classes. Intensive fruit collection by the local population and the fact that large mammals like elephants and gorilla who eat the seed and fruit respectively either destroy the seed completely or predidpose it to attack by microorganisms leading to decay. According to Peters (1994), the extraction of commercial quantities of fruits and seeds as is the practice in the study area can cause notable changes in the structure and dynamics of a tree population, which are typically precipitated by a reduction in seedling establishment due to over-harvesting. Tchamba and Seme (1993), and Beaune et al. (2012) observed that local people gather the fruits of Irvingia gabonensis and Irvingia wombolu, while many other mammals consume the fruits in the forest. They further pointed out that I. gabonensis fruits constitute a significant part of the diet of forest elephants, whereas Harris (1996) observed that squirrels and other rodents, as well as red forest pigs open the fruits to feed on the seeds, while gorillas eat the fruit. Beaune et al. (2012) observed a high mortality of $I$. gabonensis seeds and recruits resulting from a seed loss of $54 \%$ to predation, $76 \%$ to pathogens and seedling loss of $100 \%$ due to predation and pathogens. They further pointed out that this is due to density-dependent effect where the mortality of seeds, eggs or other immobile organisms is correlated with their density, which attracts predators and pathogens. Low density resources produce low yield per unit area, and are extremely susceptible to over harvesting (Peters, 1994).

The similarity in fruit production in the three forest systems could probably be that fruit production was more dependent on genetic constitutions of the particular trees involved and to a smaller extent to environmental factors which may not be very different in the three systems. Ladipo et al. (1996) observed a tree-to-tree variation in I. gabonensis fruit yield over a period of two years and pointed out that fruit set may depend on the availability of pollen and the efficiency of pollinators; but that the development of viable seeds from the ovules of pollinated flowers depends on endogenous factors and their interaction with the environment, and are both under genetic control.

The decrease in seedling survival could be attributed probably to high moisture level in the forest which provides a favorable environment for microorganism to breed and consequently affect seedlings. According to Khurana and Singh (2001), seedling population behaviour, that is recruitment, growth and survival in forests is influenced both by exogenous and endogenous disturbances. Some seedlings were observed to be eaten by animals and insects. In the same light, Peters (1994) point out that during its first year of life, a seedling is exposed to problems such as low light levels in the forest understory, the high probability of being eaten by animals and insects, outcompeted by its neighbors, smashed by a falling branch, attacked by fungal pathogens, or wilted by fluctuating moisture levels.

\section{Conclusion}

This study was carried out to assess the abundance and fruit production of Irvingia gabonensis in three forest systems, and its management and use by the local community. The goal was to determine the importance of the resource to the inhabitants of the Lobeke landscape and the availability of the resource to sustain local livelihoods. Irvingia gabonensis almonds have been indicated in this study to be a very important source of food as it is highly consumed even on a daily basis when it is available by majority of inhabitants and also constitute a major source of income. It is also available when other major food and income sources such as farm produce and cocoa are out of season thereby serving as a safety net and thus, fill the gap of food shortage and reduce malnutrition. The bark also has some medicinal and cultural values. I. gabonensis is managed by protecting wildings and mature trees during farm creation by not burning around them and very little direct planting carried out. Coupled with the low mean density of this species per hectare, it is important to sensitize collectors on the necessity to integrate I. gabonensis into different farming systems and train them on techniques of vegetative propagation through which improved planting materials can be produced in large scale.

\section{Acknowledgments}

We are grateful to PACEBCo and Wallonie Bruxelles International for funding this research and to the IDEA WILD Foundation for providing field materials.

\section{Bibliographical references}

Agbor L. O. N., 1994. Marketing trends and potentials for Irvingia gabonensis products in Nigeria. Paper presented at the ICRAF-IITA Conference on Irvingia gabonensis, Ibadan, Nigeria.

Asare R., 2005. Cocoa agroforests in West Africa. A look at activities on preferred trees in the farming system. Forest and Landscape. Working Paper $\mathrm{N}^{\circ} 6$.

Awono A., Manirakiza D., 2008. Étude de Base du Ndo'o (Irvingia spp.) dans les Provinces du Centre, Sud et Littoral Cameroun. CIFOR. Yaoundé, Cameroun, FAO-CIFOR-SNVWorld Agroforestry Center-COMIFAC, $96 \mathrm{p}$.

Ayuk E. T., Duguma B., Franzel S., Kengue J., Mollet M., TikiManga T., Zenkeng P., 1999. Forest Ecology and Management, 11 (3): 1-9.

Beaune D., Bollache L., Fruth B., Hohmann G., Bretagnolle F., 2012. Density-dependent effect affecting elephant seeddispersed tree recruitment (Irvingia gabonensis) in Congo Forest. Pachyderm, 52: 97-100. 
Belcher B., Schreckenberg K., 2007. Commercialisation of Non-timber Forest Products - A Reality Check. Development Policy Review, 25 (3): 355-377.

Brown H. C. P., Lassoie J. P. 2010. The interaction between market forces and management systems: a case study of non-wood forest products in the humid forest zone of Cameroon. International Forestry Review, 12 (1): 13-26.

Clark L. E., Sunderland T. C. H. ( Eds), 2004. The Key NonTimber Forest Products of Central Africa: State of the Knowledge. Technical Paper No. 122, SD Publication Series, USAID.

Egbe E. A., Tabot P. T., Fonge B. A., 2012. Ethnobotany and prioritization of some selected tree species in South-western Cameroon. Ethnobotany Research and Applications, 10: 235-246.

Ekobo A., 1995. Conservation of the African forest elephant (Loxodonta africana cyclotis) in Lobéké, Southeast Cameroon. PhD. Thesis, University of Kent, $151 \mathrm{p}$.

Ewane M., Ingram V., Awono A., 2009. Market chain baseline for bush mango (Irvingia spp.) in the Southwest and Eastern regions of Cameroon. Report GCP/RAF/408/EC, EU/FAOCIFOR-SNVICRAF-COMIFAC.

FAO, 1982. Fruit Bearing Forest Trees. FAO Forestry Paper 34. Rome.

Ghazoul J., Sheil D., 2010. Tropical rain forest ecology, diversity, and conservation. Oxford University Press, New York, $516 \mathrm{p}$.

Gwet J. P., 2004. Étude sur l'état des lieux des Produits Forestiers Non Ligneux autour et dans la zone communautaire du Parc National de la Lobeke. Programme Gestion Durable des Ressources Naturelles (PGDRN), GTZ/SE.

Harris D. J., 1996. A revision of the Irvingiaceae in Africa. Bulletin du Jardin Botanique National de Belgique, 65 (1): 143-196.

Ingram V., Ndoye O., Iponga D. M., Tieguhong J. C., Nasi R., 2012. Non-timber forest products: contribution to national economy and strategies for sustainable management. In: The forests of the Congo basin-state of the forest 2010. De Wasseige C., De Marcken P., Bayol N., HiolHiol F., Mayaux Ph., Desclée B.et al. Publications Office of the European Union, Luxembourg, 276 p. http://www.observatoire-comifac.net/edf2010.php?l=en

Ingram V., Schure J., 2010. Review of Non Timber Forest Products (NTFPs) in Central Africa, Cameroon. Center for International Forestry Research. IUCN, Red List of Threatened Species, Version 2013.1. [Online] http://www.iucnredlist.org/ (Accessed January 16, 2015).

IUCN, 2013. Red List of Threatened Species, Version 2013.1. [Online] http://www.iucnredlist.org/
Jiofack T. R. B., Lejoly J., Tchoundjeu Z., Guedje N. M., 2012. Agroforestry and socioeconomic potential of a non-conventional liana: Tetracarpidium conophorum (Müll. Arg.) Hutch. \& Dalz. in Cameroon. Bois et Forêts des Tropiques, 313 (3): 35-45. [Online] http://bft.cirad.fr/cd/BFT_313_35-45.pdf

Khurana E., Singh J. S., 2001. Ecology of tree seed and seedlings: Implications for tropical forest conservation and restoration. Current Science, 80 (6): 748-757.

Ladipo D. O., Fondoun J. M., Ganga N., 1996. Domestication of the bush mango (Irvingia spp.): some exploitable intraspecific variations in west and central Africa. In: Proceedings of an international conference on Domestication and commercialization of non-timber forest products in agroforestry systems, Nairobi, Kenya, p. 193-205.

Leakey R. R. B., 1998. Agroforestry in the humid lowlands of West Africa: some reflections on future directions for research. Agroforestry Systems, 40: 253-262.

Leakey R. R. B., Greenwell P., Hall M. N., Atangana A. R., Usoro C., Anegbeh P. O. et al., 2005. Domestication of Irvingia gabonensis: 4. Tree-to-tree variation in food-thickening properties and in fat and protein contents of dika nut. Food Chemistry, 90: 365-378.

Marshall E., Schreckenberg K., Newton A. C. (Eds), 2006. Commercialization of Non-timber Forest Products: Factors Influencing Success. Lessons Learned from Mexico and Bolivia and Policy Implications for Decision-makers. UNEP World Conservation Monitoring Centre, Cambridge, UK. [Online] http://www.odi.org.uk/resources/docs/3769.pdf (Accessed: December 19, 2014).

Mbile P., Ngaunkam P., Besingi M., Nfoumou C., Degrande A., Tsobeng A. et al., 2009. Farmer management of cocoa agroforests in Cameroon: Impacts of decision scenarios on structure and biodiversity of indigenous tree species. Biodiversity, 10 (4): 12-19.

McHugh M. L., 2008. Standard error: meaning and interpretation. Biochemia Medica, 18 (1) :7-13. [Online] http://dx.doi.org/10.11613/BM.2008.002

Ndoye O., Ruiz Perez M., Eyebe A., 1997.The Market of Non Timber Forest Products in the Humid Forest Zone of Cameroon. Rural Development Forestry Network. Paper 22c, ODI, London.

Njounan Tegomo O., Defo L., Usongo L., 2012. Mapping of resource use area by the Baka Pygmies inside and around Boumba-Bek National Park in Southeast Cameroon, with special reference to Baka Boumba-Bek National. African Study Monographs, Supplementary Issue, 43: 45-59.

Nkwatoh A. F., 1998. The role of processing and storage in NTFPs market price determination in Ejagham Forest Reserve Cameroon. Paper presented at the International workshop on Non-wood-forest-Products at the Limbe Botanic Garden, Cameroon, 17. 
Okolo C. O., Johnson P. B., Abdurahman E. M., Abdu Aguye I., Hussaini I.M., 1995. Analgesic effect of $I$. gabonensis stem bark extract. Journal of Ethnopharmacology, 45 (2): 125-129.

Orwa C., Mutua A., Kindt R., Jamnadass R., Simons A., 2009. Agroforestree Database: a tree reference and selection guide version 4.0. Période d'exécution : 2006 -2010, WWF. [Online] http://www.worldagroforestry.org/af/treedb/

Peters C. M., 1994.Sustainable Harvest of Non-timber Plant Resources in Tropical Moist Forest: An Ecological Primer. http://www.harmlesscoconut.com/resources/14.pdf (Accessed: November 13th 2012).

SCBD, 2001. Sustainable management of non-timber forest resources. Technical Series №6, CDB, Montreal.

Sunderland T. C. H., Besong S., Ayeni J. S. O., 2002. Distribution, utilization, and sustainability of non-timber forest products of the Takamanda Forest Reserve, Cameroon. A consultancy report for the project: "Protection of the forests around Akwaya" (PROFA).

Tabuna H., 2000. Évaluation des échanges des produits forestiers non ligneux entre l'Afrique subsaharienne et l'Europe. FAO, Accra, Ghana.

Tajoacha A., 2008. Market chain analysis of the main NTFPs in the Takamanda/Mone forest reserves, South West of Cameroon and the Cross River State of Nigeria. DEA Dissertation, Dschang, Cameroon, University of Dschang, 96 p.

Tchamba M. N., Seme P. M., 1993. Diet and feeding behaviour of the forest elephant in the Santchou Reserve, Cameroon. African Journal of Ecology, 31 (2): 165-171.

Tchoundjeu Z., Atangana A.R., 2012. Irvingia gabonensis (Aubry-Lecomte ex O’Rorke) Baill. In: Prota 7(2): Timbers 2. Lemmens, R.H.M.J., Louppe, D. \& Oteng-Amoako, A.A. (Eds). PROTA, Wageningen, Netherlands. 408-412.

Tchoundjeu Z., Duguma B., Tiencheu M. L., Ngo-mpeck M. L., 1999. The domestication of indigenous agroforestry trees: ICRAF's strategy in the humid tropics of West and Central Africa. In: Non-wood forest products of Central Africa: current research issues and prospects for conservation and development. T. C. H. Sunderland, L. E. Clark and P. Vantomme (Eds). Rome, Italy, Food and Agriculture Organisation (FAO), p. 161-170.

Tieguhong J. C., Ndoye O., 2006. Transforming subsistence products to propellers of sustainable rural development: Non-timber forest products (NTFPs) production and trade in Cameroon. Africa-Escaping the Primary Commodities Dilemma. African Development Perspective Yearbook, vol. 11, unit 1. Verlag, Berlin, p. 107-137.

Tieguhong J. C., Zwolinski J., 2008. Unrevealed economic benefits from the forests in Cameroon. IUFRO 4.05.00: emerging needs of society from forest ecosystems, University of Ljubljana, Slovenia, May 22-24, 2008.
Tsakem S. C.,Tchamba M. N., Weladji R. B., 2014. Les gorilles du Parc National de Lobeke (Cameroun) : Utilisation de habitat et implications pour la conservation. Parcs et Reserves, 69 (3): 15-25.

Ude G. N., Dimkpa C. O., Anegbeh P. O., Shaibu A. A., Tenkouano A., Pillay M., Tchoundjeu Z., 2006. Analysis of genetic diversity in accessions of Irvingia gabonensis (AubryLecomte ex O'Rorke) Baill. African Journal of Biotechnology, 5 (3): 219-223.

Van Andel T., 2006. Non-timber forest products the value of wild plants. Agrodok-series 39, CTA, Wageningen.

Van Dijk J. F. W., 1997. An assessment of non-wood forest product resources for the development of sustainable commercial extraction. CARPE: Limbe non-wood forest products workshop.

Wiersum K. F., 1997. Indigenous exploitation and management of tropical forest resources: an evolutionary continuum in forest-people interactions. Agriculture, Ecosystems and Environment, 63: 1-16.

Wong J. L. G., 2000. The Biometrics of non-timber forest products: A review of current methodology. [Online] http://m.mekonginfo.org/assets/midocs/0003270-environment-the-biometrics-of-non-timber-forest-resourceassessment-a-review-of-current-methodology.pdf (visited 18 October, 2012).

WWF, 2006. Plan d'Aménagement du Parc National de Lobeke et de sa zone périphérique. 